\title{
The Evaluation of Teaching Practice Supervisor of the Pedagogic and Professional Competence of The Students during Teaching Practice Program in Vocational Schools in Semarang
}

\author{
Eko Nugroho Julianto ${ }^{1}$, Septian Dwi Cahya ${ }^{1}$ \\ en.julianto@mail.unnes.ac.id \\ Civil Department, Engineering Faculty, Universitas Negeri Semarang
}

\begin{abstract}
Universitas Negeri Semarang is an Institute for Education Workforce Education is expected to produce a professional teacher as human resources in Indonesia. Teachers. teaching skills is the basic factor that must be owned by a teacher and always must be improved so that the quality of education that is expected to be achieved. Students who are doing everything Teaching Practice program is not able to control or enforce the competence of teachers well. This study is intended to determine the extent of mastery of professional competence and pedagogical owned by students who are doing Teaching Practice Teaching Practice Program based on Supervisor assessment. This study is a descriptive study, with a sample of 50 respondents conducted in five schools. Data analysis techniques used in this research is descriptive analysis of the percentage. From research conducted data obtained mastery of pedagogic and professional competence of students Teaching Practice Program, with an average percentage of $81 \%$ pedagogical competence and the average percentage of $83 \%$ of professional competence. Teaching Practice Supervisor stated that Student Teaching Practice Program participants stated to have a good ability to master the indicators pedagogic and professional competence.
\end{abstract}

Keywords: Evaluation, pedagogic competence, professional competence, Teaching Practice Program

\section{Introduction}

Teacher teaching skills are a basic factor that must be possessed by a teacher and must always be improved so that the expected quality of education is achieved. Because it is not impossible that teachers are an important factor influencing efforts to improve the quality and quality of education [1]. In addition to that, participant teachers and pre-service teachers have some shortcomings regarding Pedagogical Content Knowledge, pedagogical knowledge, and subject matter knowledge.[2].

Based on government regulation number 19 of 2005 article 28 paragraph 3 , it is stated that competence as a learning agent in primary and secondary education and early childhood education includes: (a) pendagogic competence, (b) personality competence, (c) professional competence, and (d) social competence [3]. Pedagogic competence is the ability of a teacher related to the level of understanding of students, the learning process and self-actualization. Personality competence is related to self-understanding, self-acceptance, self-direction and self- 
realization. Professional competence is the mastery of broad and deep learning materials, including mastery of curriculum content and the substance of scientific subjects philosophically. social competence includes the ability to communicate, get along in school and society [4].

One of the main problems of students during Teaching Practice Program is the ability to master teacher competencies. In teaching activities, of course, it involves teachers, students, curriculum, and other driving factors. If one component does not function properly, teaching activities will be disrupted and educational goals will not run optimally [1]. Quality education must be supported by professional teachers to produce people who have strong life skills and self-confidence to become competitors among others in global life [5]. This means that teacher quality is an important component to support the success of educational goals. However good the curriculum and educational facilities are, if the quality of teachers is inadequate, the educational outcomes are not as expected. The requirement to become a teacher, especially a professional teacher, is to know the ins and outs of education and teaching with various other sciences that are fostered and developed through certain educational periods [6].

The Teaching Practice Program is an intracurricular activity such as teaching, creating lesson units, and making guided and independent learning plans to meet the requirements of the educational profession. The Teaching Practice Program will later become a separate lesson for prospective teacher students when they are already working as educators. Practical field experience aims to make students become professional educators who have the knowledge, skills and attitudes that can uphold the achievement of whole pedagogical, professional, social and personality competences. According to Akinde [7] the purpose of field experience practice is to provide a contextual basis for student learning.

Based on observations made by researchers, the main problem is that students who are doing the Teaching Practice Education Program are not all able to master or apply teacher competencies properly, namely pedagogical and professional competencies. This is evidenced by the existence of class disturbances such as commotion in class, the frequent entry of students in and out of class. In addition, there are other problems such as lack of preparation in starting lessons. Teacher performance is a manifestation of teacher competence in teaching and learning in class. Teachers are required to have the ability to teach and play a professional and multifunctional role in creating an effective learning atmosphere. In the use of technology, students lack the knowledge to integrate technology in their teaching and tend to be limited in scope, variety, and depth [8].

However, not all students experience the same thing, there are also some students participating in the Teaching Practice Program who are already fluent in carrying out practical field experiences. From this problem, we want to know the results of the evaluation of the Teaching Practice Supervisor about the extent of mastery of the pedagogical and professional competencies of the Teaching Practice Program participants, because students who will carry out the Teaching Practice Program have already received courses related to pedagogical competences and professional competences.

\section{Research Methods}

This research is an educational research with percentage descriptive analysis. Descriptive research is research that aims to describe or explain something as it is in the form of a percentage. To collect data in this study, a closed questionnaire was used, which is to distribute it by directly giving a questionnaire to all civil service teachers. The form of the questionnaire 
used in this study was a checklist with five answer choices. The data analysis technique used in this study was percentage descriptive analysis. Descriptive percentage analysis is used to determine the percentage of each factor based on the respondent's answer score.

\section{Results and Discussion}

\subsection{Pedagogic Competence}

Based on the results of the descriptive percentage analysis, it can be seen that the results of the evaluation of the Teaching Practice Supervisor on the implementation of the Teaching Practice Program at State Vocational High Schools in Semarang for pedagogic competence are good with an average percentage of $81 \%$. These results are cumulative for each indicator in pedagogic competence. More details are presented in the following table.

Table 1. Evaluation results of Supervisor Teaching Practice on Pedagogic Competence.

\begin{tabular}{lcc}
\hline \multicolumn{1}{c}{ Indikator } & Persentase & Average \\
\hline Helping Students Realize Their Strengths and Weaknesses & 82 & \\
Helping Students Build Trust & 83 & \\
Openness to Students & 80 & \\
Indicator Formulation & 81 & 81 \\
Accuracy of Material and Organizing the Order of the Material & 82 & \\
Media Use & 81 & \\
Appropriateness of Evaluation Tools & 80 & \\
Ability to develop student potential & 79 \\
\hline
\end{tabular}

Based on the results of the analysis of the sub-indicators for students (Helping Students Realize Their Strengths and Weaknesses, Helping Students Build Trust and Openness to Students), it can be said that while running the Teaching Practice Program students are able to understand students. According to the results of the evaluation conducted by the Teaching Practice Supervisor, it can be said that the level of understanding of the Teaching Practice Program participants is $81,67 \%$ and is in the good category. The results of this study are in line with the results of Fanani's research [9] which states that students who get a good percentage show that some of the Teaching Practice Supervisors believe in students' abilities in helping students to realize their strengths and weaknesses, foster student self-confidence, foster enthusiasm and interest in students. , pay attention to student opinions and suggestions, involve students in the teaching and learning process, and are sensitive to the difficulties experienced by students.

In the learning design indicator with sub-indicator formulation, accuracy of material and organizing the order of the material and media use, it can be said that the evaluation results of the Teaching Practice Supervisor show that the UNNES Teaching Practice Program students have good intentions for these indicators with a value of $81.3 \%$. These results mean that the UNNES Teaching Practice Program students have good skills in learning design. Judging from the percentage score of the Teaching Practice Program students in the formulation of indicators, the use of media, the accuracy of the material and organizing the order of the material that was considered good. According to the results of research, Fanani [9] states that students who get a good percentage show that most of the Teaching Practice Supervisors believe in the ability of students to formulate indicators, accuracy in selecting materials, ability to organize material 
sequences, accuracy in selecting methods and using learning media as well as ability in designing. learning steps.

The results of the evaluation carried out by 50 Teaching Practice Supervisors for the indicator of the accuracy of the evaluation tools showed $80 \%$ results. Pamong teachers have a good opinion on the accuracy of the evaluation tools used by the UNNES Student Teaching Practice Program. This shows that the Teaching Practice Supervisor believes in the ability of the UNNES Student Teaching Practice Program in evaluating students. This can be seen in the accuracy of students in making evaluation tools that are good in testing students' knowledge of the material that has been submitted and conducting assessments on each postest and pretest.

On pedagogic abilities with indicators of developing student potential, the results of the evaluation conducted by 50 Teaching Practice Supervisors showed a result of $79 \%$. Teaching Practice Supervisors have a good opinion of students' abilities in developing student potential. This shows that the ability of the Student Teaching Practice Program in developing student potential is considered good by the Teaching Practice Supervisor as well as the role of the Student Teaching Practice Program in improving student achievement.

\subsection{Professional Competence}

Based on the percentage descriptive analysis, it can be seen that the results of the Teaching Practice Supervisor evaluation on the mastery of professional competence of students participating in the Teaching Practice Program are $81.67 \%$ and fall into the good category. The results of this study are in line with it is good. The average percentage obtained from the evaluation results by the Teaching Practice Supervisor is $83 \%$. More details are presented in the table below.

Table 2. Evaluation results of Supervisor Teaching Practice on Professional Competence.

\begin{tabular}{lcc}
\hline \multicolumn{1}{c}{ Indikator } & Persentase & Average \\
\hline Mastery of the material & 80 & \\
Ability to open lessons & 82 & \\
Asking ability & 86 & 83 \\
Ability to hold a variety of learning & 82 & 83 \\
Clarity and presentation of the material & 82 & \\
Class management skills & 86 & \\
The accuracy between the time and the subject matter & \\
\hline
\end{tabular}

These results indicate that the Teaching Practice Supervisor believes in the student's ability to master professional competences. This can be seen from the ability of students who are considered capable of mastering indicators in professional competencies such as being able to master material, being able to open lessons, ability to ask questions, being able to make variations in learning, clarity and presentation of material, ability to manage classes, accuracy between times. and subject matter.

Mastery of material for teachers is very decisive, especially in the teaching and learning process that involves subject teachers. The results of the evaluation of the Supervisor Teaching Practice on the student's ability to master the material obtained an average of $80 \%$. This shows that the mastery of Teaching Practice Program student material is good. These results are similar to research conducted by Fanani [9] which states that students participating in the Teaching Practice Program show a good percentage of mastery of the material, which means that most of the Teaching Practice Supervisors believe in the student's ability to master the subject matter. These results are also reinforced by Usman [10] who states that a teacher should always master 
the material or subject matter to be delivered and always develop it in the sense of increasing his ability in terms of his knowledge because this will greatly determine student learning outcomes. With sufficient mastery of learning materials, students will be able to teach optimally and if teaching and learning activities are maximized, the learning outcomes obtained are also maximized.

Skills to open lessons are activities and teacher statements that are carried out for the first time in learning activities, carried out with the aim of creating a mentally prepared atmosphere and causing student attention to be focused on the things to be learned. With an average percentage of $82 \%$, it means that the Teaching Practice Program students are able to open lessons well. According to Usman [10] opening activities are not only carried out by the teacher at the beginning of class hours, but also at every piece of activity that is carried out such as starting a question and answer activity or about new concepts.

In the teaching and learning process asking questions plays an important role, because wellstructured questions and proper throwing techniques will also have a positive impact on students. Based on the average percentage obtained by $86 \%$, this shows that the Teaching Practice Supervisor believes in the ability of students to ask questions to students, both in terms of the quality of the questions and sentences used. According to research results, Fanani [9] stated that the Teaching Practice Program students were $81.67 \%$ and were in the good category. The results of this study are in line with the percentage very well, indicating that most of the Teaching Practice Supervisors are very confident in the ability of students to ask questions to students, both in terms of the quality of the questions and the sentences used. These results are in accordance with the opinion of Usman [10] which states that the skills and fluency of asking a teacher include the content of questions and questioning techniques and are in accordance with the theory presented by Mulyasa [11], namely that questioning skills really need to be mastered by the teacher to create effective and fun learning, because almost in every stage of learning the teacher is required to ask questions, and the quality of the questions asked by the teacher will determine the quality of the students' answers.

Holding variations is a skill that teachers must master in learning, to overcome the boredom of students, so that they are always enthusiastic, diligent, and full of participation. Variations in learning are changes in the process of activities aimed at increasing students' motivation to learn, and reducing boredom and boredom [11]. According to the Teaching Practice Supervisor, the ability of students to make variations is good with an average ability to vary by $82 \%$. This means that some of the Teaching Practice Supervisors believe in the ability of students to carry out variations in learning, both in terms of material delivery, using and applying learning methods. This condition is in line with the results of research by Fanani [9] saying that the Teaching Practice Program students fall into the good category. With these results, it means that the Teaching Practice Supervisor is very confident in the ability of students to make variations both in terms of material delivery, use of methods and in the use of learning media. This ability is also strengthened by Slameto's statement [12] which states that teachers must use many methods in teaching. Variations in methods will result in the presentation of learning materials to attract the attention of students and the class to be more lively, the method of presentation which is always the same will bore students.

Explaining is an important aspect that teachers must have, considering that most learning requires teachers to provide explanations. In addition, so that the explanation given can be understood, the presentation of the material must be good, coherent, and easy to understand. The results of the analysis show that the student's ability to explain and present the material is good, this is indicated by the mean value for this ability of $83 \%$ and this condition shows that the Teaching Practice Supervisor is fully confident in the ability of the Teaching Practice 
Program students in clarity and presentation of the material. This is in line with the results of a similar research conducted by Fanani [9], which stated that the Teaching Practice Program students showed good results in the clarity and presentation of the material. The results of this study are also reinforced by the opinion expressed by Usman [10] which states that providing information is a very important aspect of teacher activities in their interactions with students in class, so the delivery of information must be good and presented in a suitable order.

The ability to manage the classroom is the teacher's ability to design, organize and organize the curriculum, translate it into teaching procedures and learning resources, and organize the learning environment to achieve an effective and efficient teaching atmosphere. The result of the evaluation of the Teaching Practice Supervisor on the students' ability in the Teaching Practice Program was $82 \%$ with good criteria. This shows that the Teaching Practice Supervisor is very confident in the ability of the Teaching Practice Program students in managing the class. This can be seen from the way students are able to open and close lessons well, besides that students are able to create a conducive learning environment by arranging classroom layouts for teaching and creating a suitable teaching and learning climate so that students can study calmly and comfortably. The results of a similar study conducted by Fanani [9] also stated that the Teaching Practice Program students showed a very good percentage of class management skills, this shows that most of the Teaching Practice Supervisors are very confident in the student's ability to manage the class. These results are also reinforced by the opinion of Usman [10] which states that the quality and quantity of students in the classroom depends on many factors, including: teachers, personal relationships between students in the classroom, and general conditions and atmosphere in the classroom.

The result of the evaluation of the Teaching Practice Supervisor on the ability in accuracy between the time and material of the Teaching Practice Program students was $86 \%$ and it was in the good category. This shows that the Teaching Practice Supervisor believes in the ability of the Teaching Practice Program students in the accuracy between time and material. These results are similar to the results of research conducted by Fanani [9] where in the study the Teaching Practice Supervisor stated that the Teaching Practice Program students were able to adjust the material to the time.

\section{Conclusion}

Based on the results of the research, it can be concluded that the mastery of the students' competency in the Field Experience Practice is as follows:

1. The results of the evaluation of the Teaching Practice Supervisor on the pedagogical competence mastery of the students of the Semarang State University Teaching Practice Program are good with an average percentage of $81 \%$.

2. The results of the evaluation of the Teaching Practice Supervisor on the mastery of the professional competence of the Semarang State University Teaching Practice Program students are good with an average percentage of $83 \%$.

\section{References}

[1] Sevgi Aydin, Yezdan Boz: Review of Studies Related to Pedagogical Content Knowledge in the Context of Science Teacher Education: Turkish Case. Educational Sciences: Theory \& Practice - 12(1): Winter, 497-505 (2012) 
[2] Widya Febriati: Persepsi Guru Terhadap PPLK Prodi Sejarah. Jurnal Pendidikan 1(1):1-5 (2015)

[3] Government Regulation No. 19 of 2015 National Education Standards 16 May 2005. State Gazette of Indonesia 2005 Number 41, Jakarta

[4] Adnan Hakim: Contribution of Competence Teacher (Pedagogical, Personality, Professional Competence and Social) On the Performance of Learning. The International Journal Of Engineering And Science 4(2):1-12 (2015).

[5] Hasan Tanang, Bahari Abu: Teacher Professionalism and Professional Development Practices in South Sulawesi, Indonesia. Journal of Curriculum and Teaching 3(2):25-42 (2014).

[6] Rita Mariyana: Kompetensi Guru Dalam Pembelajaran Berbasis Pendidikan Karakter Anak Usia Dini. Jurnal Ilmu Pendidikan:1-18 (2013).

[7] Oluwatoyin Adenike Akinde, Diane Harr, Phyllis Burger: Field Experience: Experiential Learning as Complementary to the Conceptual Learning for International Students in a Graduate Teacher Education Program. International Journal of Higher Education 6(4):131-151 (2017).

[8] Matthew J. Koehler, Punya Mishra, Kristen Kereluik, The Technological Pedagogical Content Knowledge Framework".Handbook of Research on Educational Communications and Technology 9(1):101-111 (2014)

[9] Fanani,M.Z.: Persepsi Guru Pamong Terhadap Pelaksanaan PPL Mahasiswa. Jurnal Kependidikan 14(2):220-233 (2016).

[10] Usman,M.U.: Menjadi Guru Profesional. Bandung: Remaja Rosdakarya (2001).

[11] E. Mulyasa: Menjadi Guru Profesional. Bandung: Remaja Rosdakarya (2005).

[12] Slameto: 2003. Belajar dan Faktor-Faktor yang Mempengaruhinya. Jakarta : PT. Rineka Cipta (2003) 